\title{
Beyond scarcity: Rethinking water, climate change and conflict in the Sudans
}

\author{
Jan Selby ${ }^{\mathrm{a}, *}$, Clemens Hoffmann ${ }^{\mathrm{b}}$ \\ ${ }^{a}$ Department of International Relations, University of Sussex, Brighton BN1 9QN, UK \\ ${ }^{\mathrm{b}}$ Department of International Relations, Bilkent University, 06800 Ankara, Turkey
}

\section{A R T I C L E I N F O}

\section{Article history:}

Received 23 April 2013

Received in revised form 6 January 2014

Accepted 8 January 2014

Available online 21 February 2014

\section{Keywords:}

Water

Conflict

Climate change

Scarcity

Sudan

\begin{abstract}
A B S T R A C T
This article develops a new framework for understanding environment-conflict relations, on both theoretical grounds and through a qualitative historical analysis of the links between water and conflict in the states of Sudan and South Sudan. Theoretically, the article critiques the dominant emphases on 'scarcity', 'state failure' and 'under-development' within discussions of environmental security, and proposes an alternative model of environment-conflict relations centring on resource abundance and globally-embedded processes of state-building and development. Empirically, it examines three claimed (or possible) linkages between water and conflict in the Sudans: over trans-boundary waters of the Nile; over the links between internal resource scarcities and civil conflict; and over the internal conflict impacts of water abundance and development. We find that there exists only limited evidence in support of the first two of these linkages, but plentiful evidence that water abundance, and state-directed processes of economic development and internal colonisation relating to water, have had violent consequences. We conclude that analysts and policymakers should pay more attention to the impacts of resource abundance, militarised state power and global political economic forces in their assessments of the potential conflict impacts of environmental and especially climate change.
\end{abstract}

(c) 2014 Elsevier Ltd. All rights reserved.

\section{Introduction}

Mainstream academic and policy accounts of the relations between environmental change and conflict, including the conflict potential of global climate change, are usually organised around three sets of ideas: 'scarcity', 'state failure' and 'under-development'. Scarce resources are envisaged as challenging livelihoods, fomenting grievances and competition, and spurring civil and perhaps even inter-state conflict. Weak state authority is held to facilitate, or do little to mitigate, the development of these dynamics. And widespread poverty and a low level of development are equally thought to be crucial contextual factors, on the grounds that resource scarcity primarily affects the lives of poor people in poor countries. These motifs have not gone unchallenged, of course. Scarcity discourse, in particular, has been extensively critiqued on both theoretical and empirical grounds, with some finding scant evidence of links between environmental scarcity and conflict (esp. Theisen, 2008), and others calling attention to the problematic political agendas associated with, and the negative

\footnotetext{
* Corresponding author. Tel.: +44 1273876694 .

E-mail addresses: j.selby@sussex.ac.uk (J. Selby), clemens@bilkent.edu.tr (C. Hoffmann).
}

consequences of, scarcity framings (Leach and Mearns, 1996; Mehta, 2010). Yet 'scarcity', 'state failure' and 'under-development' remain the dominant policy and academic ideas. And critical scholarship on these themes has been more oriented to critiquing these constructions, especially 'scarcity', than proposing alternative models of environment-conflict relations.

This article seeks to advance just such a new model, on both theoretical grounds and through a qualitative historical analysis of the links between water and conflict in the states of Sudan and South Sudan. The two Sudans (or, prior to southern secession in 2011, the single state of Sudan) have long served as textbook cases within environmental security thinking. Images and headlines of drought, famine and conflict dominate Western public, and to a degree expert, understandings the two countries. Both chronic and environmental shock-induced water scarcities are often identified as important contributory factors to their high levels of political violence (Assal, 2006; Bromwich, 2009). And Sudan is regularly portrayed as site of the world's first global climate change-induced war, in the troubled western region of Darfur (Mazo, 2010, pp. 7386; Mjøs, 2007). Sudan generally and Darfur specifically are often held up as providing paradigm-defining evidence of our looming future of climate change-induced conflicts. 'Let Darfur stand as the starkest of warnings about what the future could bring,' claims one report (Christian Aid, 2007, p. 2). Moreover, both of the Sudans are 
regularly characterised as 'failed', 'failing', 'fragile' or 'weak' states (Ellis, 2005), and as desperately under-developed (Keen, 2001), these failings in turn being understood as important contextual or contributory factors in their experiences of scarcity-induced conflict. The Sudans thus serve as a perfect case for testing mainstream environmental security (and specifically water and climate security) thinking, and for suggesting an alternative model of environment-conflict relations.

The article is structured as follows. Immediately below we provide a cursory overview of contemporary environmental conflict discourse; critique on theoretical grounds its overwhelming emphases on scarcity, state failure and under-development; and outline an alternative model of environment-conflict relations. We then briefly summarise our case study methodology. Thereafter we turn to the Sudans, considering three different sets of claimed (or possible) links between environmental change and conflict: (1) over the trans-boundary resources of the Nile; (2) over internal water scarcities; and (3) over internal water abundance and projects of agricultural and water development. We find that there exists only limited historical evidence in support of the first two of these linkages, but plentiful evidence that water abundance, and state-directed processes of economic development and internal colonisation relating to water, have had violent consequences. The conclusion expands on this core finding and also considers the potential purchase of this model under future circumstances of global climate change.

\section{The environment and conflict revisited}

The idea of 'scarcity' provides the central organising concept within contemporary environmental conflict discourse, including on the conflict potential of water stresses and global climate change. Understood sometimes in Malthusian terms (as arising when population growth and consumption approach natural limits) and sometimes through the lens of neo-classical economics (as an inherent property of all economic goods), scarcity is assumed to generate frustration, competition, grievances, and in turn, potentially, conflict. Thus the UN Secretary General has recently claimed that, within the context of climate change, [c]ompetition between communities and countries for scarce resources, especially water, is increasing, exacerbating old security dilemmas and creating new ones' (Ban, 2011). Many scholars have broadly concurred. The central thesis of the leading exponent of post-Cold War environmental security discourse, Thomas HomerDixon, is that 'environmental scarcity causes violent conflict' (1999, p. 93). Peter Gleick, leading authority on water and international security, presents water's scarcity as the primary characteristic that makes it a likely 'source of strategic rivalry' (1993, p. 84). And the Intergovernmental Panel on Climate Change has concluded that climate change 'may exacerbate resource scarcities in developing countries,' in turn potentially generating 'scarcity disputes between countries, clashes between ethnic groups, and civil strife and insurgency' (2001, p. 950); and that 'climate change may become a contributory factor to conflicts in the future, particularly those concerning resource scarcity, for example scarcity of water' (2007, p. 443). More recent quantitative scholarship has tended to find only limited support for the scarcity-conflict thesis (see e.g. Gleditsch, 2012; Johnson et al., 2011 for overviews); and the mainstream concern with scarcity has also been extensively critiqued by political ecologists on theoretical, political and evidential grounds (e.g. Peluso and Watts, 2001; Benjaminsen, 2008). Nonetheless, the belief that scarcity can cause or contribute to conflict, and will do so increasingly in future, remains the core framing idea and reference point - even when this is only a point of departure - within environmental conflict debates.
Alongside but secondary to this, most academic and policy discourse on environmental conflict also places significant emphasis on institutional and economic factors as important intervening or contextual causes of scarcity-related conflict. Specifically, economic 'under' or 'low' development, and 'failed' or 'weak' statehood, are routinely depicted as pivotal in determining whether resource scarcities generate conflict or not. In some academic accounts, 'constrained economic productivity' and 'disrupted institutions' are considered effects of environmental scarcity, and thus important pathways to conflict (HomerDixon, 1999, pp. 81-103). In others, by contrast, these institutional and economic factors are viewed as independent variables which typically precede but then interact with scarcity crises (Baechler, 1999, pp. 41, 103; Kahl, 2006, pp. 24-26). For most, low economic development is such a crucial variable that the analysis of environmental security challenges can be restricted, a priori, to poor countries: as Nordas and Gleditsch observe, this assumed connection between environmental conflict and poverty 'is not a point of great controversy in the literature' (2007, p. 635). Likewise, state failure, weakness and contraction are typically viewed as key. This is especially the case within policy discourse (e.g. CNA Corporation, 2007, p. 44; UK Cabinet Office, 2008, p. 18), but also holds true of much of the best academic analysis: Barnett and Adger observe, for instance, that 'when states contract ... violent conflict [over scarce resources] is more likely' (2007, p. 647). The basic assumption operative here is that the environmental conflict problematique is to a significant degree caused or mediated by political and economic weaknesses that are internal to nonWestern states.

For the purposes of this article, there are five problems with the above that need highlighting. First, the widespread assumption that environmental conflicts should be analysed through the lens of 'scarcity', when other resource conflicts are generally seen as arising from 'abundance' (Koubi et al., 2013), is paradoxical and indeed flawed. Within the extant literature on the political economy of civil wars, resource 'abundance' is generally seen as the key variable, the high prevalence of diamonds, oil, and other non-renewable resources being closely linked to conflicts, in SubSaharan Africa in particular (e.g. Collier and Hoeffler, 2005; Fearon, 2005). This is puzzling: the mechanism linking rare minerals and non-renewables with conflict is held to be the 'resource curse' of 'abundance', while the condition linking water-the most abundant renewable resource on the planet-with conflict is thought to be 'scarcity'. This latter linkage is typically justified on the grounds that disruptions in the availability of environmental resources such as water can contribute to economic decline, social discontent, competition and in turn conflict-a causal chain which is theoretically plausible, if often contested. Even if it is valid, however, water could also be associated with conflict through abundance. The resource curse literature typically argues that local abundance can lead to conflict by creating incentives for parties to engage in conflict, by providing the state and especially rebels with the financial means to sustain conflict, and/or by weakening state institutions and transforming state-society relations (e.g. Collier and Hoeffler, 2005; Fearon, 2005). There is little reason, in principle, why these or some other abundance-related causal dynamics could not also apply to water.

Second, the assumption that some resource conflicts are associated with 'scarcity', whilst others are caused by 'abundance', is theoretically incoherent-for the simple reason that scarcity and abundance are relational concepts, which, like the terms 'master' and slave', only make sense in relation to one another. Approached thus, 'scarcity' does not refer to an objectively small quantum of resources, but instead to a circumstance in which some individuals or groups have less than others (i.e. socially), or than they have in other places (i.e. spatially), or than they had at other times (i.e. 
temporally). Very much the same applies to 'abundance'. The resource curse of diamonds has often been associated with civil war in the likes of Angola and Sierra Leone-but local 'abundance' in such countries only exists relative to global 'scarcity', and to this extent all precious gem and mineral-related conflicts must be as much about the latter as the former. Indeed, the illusion that 'scarcity' and 'abundance' are discrete variables is only sustained by a state-centric political imaginary and the quantitative datasets that accompany it. Thus the challenge is not so much to understand whether it is resource scarcity, or abundance, which is most associated with conflict; but instead to treat these two concepts as essentially paired-'scarcity-abundance'-and as referring to relative differences across society, space and time, and to investigate whether and how these relative differences are, or might become, associated with conflict.

Third, there are grounds for thinking that it is not the relative scarcity or abundance of particular environmental resources, but rather their relative economic and political value, which is the major determinant of their conflict potential. As already noted, within the existing literature non-renewable resources are often linked to conflict through the mechanism of abundance, while renewable environmental resources such as water are usually analysed through the lens of scarcity (Koubi et al., 2013). But the high conflict potential of for instance diamonds does not essentially lie in their abundance, so much as in their high value. Equally, the intimate links between oil and military conflict are above all rooted in the former's economic and political value, oil being both the mainstay of global mass consumer society, and a vital source of, or potential route to, wealth and power for producer state elites and the various worldwide economic and political interests linked to them (especially in the oil, financial and military production sectors). In most contexts, environmental resources are, by contrast, of relatively low economic and political value: water, for instance, is generally not a route to wealth and power (Selby, 2005a). It is arguably essentially for this reason that there have been no modern inter-state 'water wars' (Wolf, 1998): within the context of contemporary global capitalism, environmental resources like water are just not of sufficient value to be a priority for economic and political elites (Selby, 2005a).

Fourth, academic and policy discourse on scarcity (or abundance, in the resource curse literature) is almost always premised on a mechanistic and geographically deterministic understanding of resource conflict. The point here is not simply, pace Gleditsch et al., that most conflicts are not 'over some type of resource perceived as scarce' (2006, p. 362), or even that conflicts are typically caused by various historically and socially specific political, ideological, economic and identity factors that go well beyond resource availability and distribution. Just as significantly, these non-resource factors structure how resources are approached and valued. The extant literature almost always analyses whether and how environmental changes (e.g. sudden or secular changes in precipitation) or increases in demand (from population growth or increased per capita consumption) determine or contribute to conflict. But this overlooks the possibility that resource-related conflicts can occur without any change in, or irrespective of, supply-demand balances, for instance through the rise of new ideologies, policies or political and economic structures which result in the resources in question being deemed more valuable and conflict-worthy than hitherto. For example, repeated US and UK military interventions in Middle Eastern oil states have not been rooted in sudden or secular changes in the availability of oil, but in specific political and economic interests and strategies. Equally, 'blood diamond' conflicts have not been structured by changes in the prevalence of diamonds, but rather by the consistently high value ascribed to them by Western consumers under the influence of De Beers and the worldwide advertising industry. If and when scarcity-abundance is an important causal factor within conflicts, this is not because it mechanically determines behaviour, but to the extent that it is deemed and interpreted as important by parties to conflict, within the context of global political economic structures.

Equivalent problems bedevil the widespread emphases on state failure and under-development. The idea of 'state failure' has been widely critiqued as an essentially normative rather than analytical concept, that is more a product of various post-Cold War Western security interests than a tool of rigorous political analysis (e.g. Call, 2008; Logan and Preble, 2010). As an analytical tool, however, its central emphasis and value is in pointing to the problems that emanate from weak and disintegrating state institutions, that is, from a lack of sovereign state control over populations and territory. There are at least two problems here. Firstly, many of the gravest insecurities in the global South arise not just from state weakness, but rather from militarised state strategies and processes of statebuilding and internal colonisation which in the contemporary global South, as previously in Europe, have necessarily involved widespread violence and dispossession (Stavrianakis and Selby, 2012). Secondly, many of these insecurities and state strategies have important international and geopolitical dimensions, rather than being mere internal characteristics of the 'failed states' in question. To illustrate from an earlier historical era, the devastating climaterelated famines experienced across India, China, Brazil and elsewhere during the late nineteenth century were, in their political dimensions, essentially products of British imperial power and doctrine, not weak local governance (Davis, 2002). The role of aggressive state institutions and strategies in creating or exacerbating resource insecurities is sometimes recognised within the environmental security literature: Kahl (2006), for instance, analyses both 'state failure' and 'state exploitation' resource conflicts. But most academic and virtually all policy discourse remains inattentive to these exploitative state and international dimensions of resource-related conflicts.

Sixth and finally, the emphasis on 'under-development' as a cause of scarcity conflicts is problematic for similar reasons. The under-development thesis draws heavily on recent econometric research on civil wars which has repeatedly concluded that poverty and low development are closely correlated with civil war (e.g. Murshed, 2002). There are three problems here, each of which also applies to the environmental security literature. Firstly, such claims about the correlation between poverty and violence are historically myopic: yes, civil wars since the 1980s have been overwhelmingly concentrated in the global South, most notably Sub-Saharan Africa, but this has not been the case in earlier historical eras, and thus need not be in the future (see e.g. Halperin, 2004). There is thus no necessary a priori reason why environment and resource-related conflicts should be limited to, or emanate from, poor states. Secondly, against the assumption that poverty and low development cause conflict, it has historically been the case that processes of economic and social development have themselves been inherently conflictual, and inherently violent. Indeed, both historically (Moore, 1967) and in the contemporary South (Cramer, 2006), war has had formative productive impacts on, and been an abiding characteristic of, 'development'. Moreover, thirdly, under-development is never merely an internal characteristic of poor states and societies, but a product also of their structural positioning and insertion into a highly uneven and hierarchical world economy. What this suggests is at least the theoretical possibility that environment-related conflicts may be caused, not by local and internal development deficits, but instead by processes of development that are internationally structured, or even sanctioned.

These six lines of critique suggest an alternative model for understanding the relations between the environment and 
conflict, as follows. A first guiding premise of this model is that it is relations and processes (the social, geographical and temporal relations between 'scarcity' and 'abundance'; and processes of statebuilding and development) rather than objective conditions, levels or variables (e.g. levels of scarcity or of development) which are the key to understanding the links between the environment and conflict. Linked to this is a second premise: that these relations and processes are not defined or limited by state boundaries, and cannot be understood through the analytical lens of statecentrism, but instead operate at multiple local, national, international and global scales, and are also multi-scalar in their causes. Building on this, our hypotheses track the six lines of critique above: first, that relative local environmental abundance is more intimately associated with conflict than local environmental scarcity; second, that such local abundance only assumes importance relative to 'scarcities' elsewhere; third, that it is the relative political and economic value of different environmental resources, rather than their abundance or scarcity, which is the major determinant of their conflict potential; fourth, that it is political processes and economic dynamics, rather than changes in resource availability, which are the main proximate determinants of environment-related conflict; and finally, that the most important such dynamics are local processes of state-building and development, which are in turn embedded in broader geopolitical and global political-economic relations.

\section{Methodology}

To test these hypotheses, we undertake below a qualitative historical analysis of water-conflict relations in a single (large) case study area, Sudan. We focus on water specifically since, of all environmental resources, it is water which is most often associated with scarcity-induced conflict. Similarly, we focus on Sudan since it is often viewed as a textbook case of environmental security, as indicated above. Theoretically, our analysis is principally informed by historical materialist scholarship in International Relations (Halliday, 1994; Rupert and Smith, 2002) and Geography (Harvey, $1996,2009)$, though it also owes much to work in political ecology (Peluso and Watts, 2001). In line with these approaches, we view development and state formation as inherently conflict - laden and violent processes - in Sudan as elsewhere, including historically in Europe (Ayers, 2010; Tilly, 1985). Also in line with these approaches, as well as our critical comments above, our method is intentionally qualitative: the analysis of multi-scalar processes and relations demands just such a method, and cannot coherently be pursued through a quantitative analysis of correlations between supposedly distinct 'variables'. We test three sets of claimed (or possible) links between water and conflict in Sudan: (1) over transboundary waters of the Nile; (2) over the links between internal Sudanese resource scarcities and civil conflict; and (3) over the internal conflict impacts of water abundance and development. The analysis draws upon fieldwork conducted in South Sudan during 2011 and 2012, plus existing literatures on Sudanese history, political economy and the environment. Of this existing literature, we should mention in particular the significant parallels between our analysis and that of Verhoeven (2011b). However, whereas Verhoeven's main concern is to critique mainstream environment-conflict narratives as they have been invoked in relation to Sudan, we aim here to go a step further and offer an original positive account of environment-conflict relations that is relevant not only to Sudan, but also beyond.

\section{Scarcity and competition on the Nile}

The claim that the limited water resources of the River Nile are subject to increasing pressures and competition, leading to growing strategic rivalry and potentially to inter-state conflict, is a staple of the water security literature. Indeed, within much of this literature, the prospects for conflict over the Nile are discussed more than any other case (e.g. Gleick, 1993; ICA, 2012). This concern about Nile geopolitics is founded on three main factors: the high levels of population and economic growth within the Nile basin states, which are deemed likely to increase pressure on supplies; the extreme dependence of the downstream riparians, especially Egypt, on transboundary Nile flows; and the absence of any basin-wide water management regime amongst the eleven (including South Sudan) Nile riparians. Egypt, in particular, faces an undoubtedly challenging situation, being 97\% dependent on transboundary flows (FAO, 2009), and facing the prospect of 500 cubic metres/capita/year ( $\mathrm{m}^{3} /$ year) water availability by 2025 , according to its Ministry of Water Resources and Irrigation (Moussa, 2012; MWRI, 2010) - which, by the most widely used measure of water stress, would place it in the category of 'absolute scarcity' (Falkenmark, 1989). Securing the Nile is often said to be Egypt's primary consideration in its relations with Sudan and upstream riparians and, indeed, Nile state leaders have repeatedly raised the prospect of war over access to it. President Sadat observed, for instance, that 'we depend upon the Nile $100 \%$ in our life, so if anyone, at any moment, seeks to deprive us of our life, we shall never hesitate to go to war' (Waterbury, 1979, p. 78). Egyptian Foreign Minister Boutros Ghali declared in 1990 that 'the next war in the Middle East will be over water, not politics' - an unfortunate statement not only in its assumption that water is extra-political, but also in its timing, just before Iraq's invasion of Kuwait (Selby, 2005b, p. 339). In 2010, Ethiopian Prime Minister Meles Zenawi accused Egypt of supporting rebel forces in his country, in order to prevent it from developing the Nile (Malone, 2010). And just prior to his overthrow, Egyptian President Morsi implied that Cairo might respond militarily to Ethiopian dam construction, threatening that if the Nile 'diminishes by one drop, then our blood is the alternative' (Verhoeven, 2013).

Yet for all this rhetoric, post-colonial Sudan has not been a site of, or party to, any significant trans-boundary conflict over the Nile, despite accounting for over $60 \%$ of the river's total basin area. Hydropolitical relations between Sudan and Egypt have historically been characterised much more by cooperation than conflict. To this day, these relations remain governed by the terms of the 1959 Nile Waters Agreement, which codified Sudanese and Egyptian Nile allocations, sanctioned the construction of the Aswan High Dam in Egypt plus the Roseries Dam in Sudan, and established a Permanent Joint Technical Commission to oversee the coordinated management and development of the river (UAR/Sudan, 1959). Moreover, Sudan's actual utilisation remains well below its annual allocation of 18.5 billion $\mathrm{m}^{3}$ (annual abstraction from the Nile varies between 10 and $16 \mathrm{bm}^{3}$ /year: Hamad, 1998; Omer, 2007, p. 2070). Sudan is currently engaged in an ambitious dam-building programme, which may bring its average utilisation close to this 1959 allocation (Verhoeven, 2011a, p. 19). However, all Sudanese dam-building activity has been explicitly or implicitly approved by Egypt (Swain, 2011, p. 699; Taha, 2010, p. 196). Indeed, rather than trying to prevent increased Sudanese utilisation, Egypt is actively participating in the expansion of Sudanese agriculture, through its 'African farms' strategy (Ali, 2011; MALR, 2012). Of course, this hydropolitical cooperation is between Egypt and Sudan alone, excluding upstream riparians; and even this bilateral 'cooperation' may be considered an instance of Egyptian 'hydro-hegemony', a means through which Egypt maintains institutionalised hegemony over the Nile (Zeitoun and Warner, 2006). Nonetheless, it remains the case that Egyptian-Sudanese water relations have not been marked by any significant, let alone violent, conflict.

Equally, Nile waters have not been a key issue, or source of dispute, within the Sudanese peace process. The 260 page-long 
2005 Comprehensive Peace Agreement barely mentioned water issues, and accounts of the three years of negotiations underpinning the Agreement suggest that the Nile barely figured at all (Johnson, 2011; Young, 2012). Under the Comprehensive Peace Agreement, Nile water management remained under the exclusive jurisdiction of the national government (GoS and SPLM/A, 2005: Chapter II, Part 5, Schedule A: 33). Similarly, water issues did not receive any great time or attention during the 2005-2011 interim phase of the peace process, and have not featured prominently in post-referendum negotiations (ICG, 2011; UNSC, 2011). Indeed, next to the other outstanding post-secession issues - final border demarcation, oil revenue sharing, the status of Abyei, citizenship, and population return, as well as the military conflict in Blue Nile and South Kordofan states - water appears to have been very far from a priority. A conjunction of three factors probably lies behind this. Firstly, the Comprehensive Peace Agreement's definition of Nile water management as Khartoum's competence, plus the limited attention paid to water issues since then, reflects the North's status quo interests in maintaining and perhaps extending its control over the Nile (Granit et al., 2011, p. 25). Second, there is little immediate demand for increased utilisation of the Nile in South Sudan: almost all agricultural production there is rain-fed; there were no functional pump irrigation projects in the South when the Comprehensive Peace Agreement was concluded in 2005 (Salman, 2011, p. 161); major abstraction of Nile waters remains years away; and other issues, especially regarding oil revenues and security, were for obvious reasons deemed more immediate priorities in laying the foundations for a new state. Thirdly, the Sudan People's Liberation Movement may have deemed it sensible to delay discussion of the Nile given the issue's potential to complicate relations with other Nile riparians and even jeopardise the peace process (Salman, 2011, pp. 161-162). As it happens, these external actors' hydrosecurity concerns have not been major sources of dispute within the peace process. Egypt was often said to be hostile to the idea of southern secession, in large part for hydro-political reasons (e.g. ICG, 2010, pp. 10-11; Johnson, 2003, p. 43). However, in the event Egypt supported the South's secession after South Sudanese President Salva Kiir, keen to warm Cairo to the idea of independence, provided assurances that Egyptian water supplies would not be affected (Wikileaks, 2010). Egypt has since developed good political and water relations with independent South Sudan, building on its long-established colonial and postcolonial expertise on the region's hydrology (Interview, 2011a, 2011b). Without idealising these water relations - which involve hydro-hegemonic 'control through cooperation' - it is nonetheless evident that Sudan's partition has not led to, or involved, water scarcity-related conflicts.

Beyond these Sudan-specific issues, caution is also due on the overall validity of Nile scarcity discourse. For all the talk of looming water scarcity, there has been no average decline in Nile flow through Sudan since the 1960s, no decline in the water level of Lake Nasser, and no decline in the volume of water released into Egypt through the High Aswan Dam. Indeed, during the ten years 2000-2010, an average $60.8 \mathrm{bm}^{3} /$ year were released through the High Aswan Dam (Abdel-Latif and Yacoub, 2011, pp. 89-90) - well in excess of the $55.5 \mathrm{bm}^{3} /$ year allocated to Egypt under the Nile Waters Agreement. Egypt continues to expand its irrigated agriculture, notably in the Toshka, East Owainat, Darb al-Araba'in and As-Salam Canal projects (Barnes, 2012, p. 518). Future population and agricultural expansion in Egypt, and any equivalent development in Ethiopia and other upstream riparians, will of course place greater pressure on Nile waters. But there is no evidence as yet of scarcity imposing limits on utilisation and development, let alone evidence of such scarcities generating, or contributing to, trans-boundary conflicts.

\section{Scarcity and civil conflict in Sudan}

Parallel to this questionable discourse of trans-boundary conflict on the Nile are the frequent claims that internal water scarcities within Sudan are already generating or contributing to civil violence. International and Sudanese actors alike have regularly identified such linkages, especially in relation to Darfur. In the UK alone, the Ministry of Defence (DCDC, 2010, p. 106), a Secretary of State for Energy and Climate Change (Huhne, 2011), and leading think tanks (Mazo, 2010) and NGOs (Christian Aid, 2007), amongst others, have all interpreted conflict in Darfur as caused or compounded by water stresses. In North America, Thomas Homer-Dixon has done likewise (Homer-Dixon, 2007), as have Jeffrey Sachs, Professor of Economics at Columbia University (Sachs, 2006, 2005), former US Vice President Gore (2006), and leading academic analysts of Sudanese politics (de Waal, 2007a; Mamdani, 2009). Ban has not only described the Darfur conflict as beginning 'as an ecological crisis, arising in part from climate change' (Ban, 2007), but has also asserted that 'if you don't deal with the issue of water in Darfur ... then there will be no solution at all' (Hokanson, 2007) - a verdict corroborated by Ibrahim Gambari, head of the African Union/UN mission in Darfur, who contends that 'water scarcity ... imperil[s] our common efforts to achieve peace and stability in Darfur' (UNAMID, 2011). Sudan's President Bashir (Tisdall, 2011) and Foreign Minister Ali Karti (SUNA, 2009) have both explained the Darfur war as a product of climate-change induced water scarcities, Bashir's account being typical: 'What happened in Darfur, first of all, was a traditional conflict taking place from the colonial days. Under all (previous) national governments, there were tribal conflicts in Darfur, because of the frictions between the shepherds and the farmers. These kinds of frictions increased because of climate change and the dry weather which also increased the movement of people and herds, which led to more friction.' Such linkages have also been drawn in relation to South Sudan. For example, one commentator claims that 'most of the conflicts which have plagued Southern Sudan' since the 2005 Comprehensive Peace Agreement 'are water access related' (Luoi, 2010), while South Sudan's Minister of Labour has claimed, speaking at a reconciliation conference between groups from Lakes and Warrap states, that 'accessibility to water is the main problem' [sic] (Mayoum, 2010). Most such discourse on Sudan is predicated on a similar set of claims or assumptions: that internal Sudanese water scarcities and attendant processes of desertification are a source of and to some degree correlated with conflicts; that these scarce water resources are principally fought over by competing pastoralists and farmers; that such conflicts are also products of, or are compounded by, subsistence livelihoods, low development and weak state control; and often, that the water scarcities are partly caused by anthropogenic climate change.

There are three sets of problems with such claims. Firstly, they receive only the thinnest support from, and in some cases are contradicted by, the actual record of recent environmental change in Sudan. Consider first Darfur, which has been the primary focus of such claims. The Darfur war broke out in 2003, with the violence being at its height between then and 2005. Yet during this three year period, Darfur experienced above average rainfall (Kevane and Gray, 2008; UNEP, 2008, pp. 8, 11). Moreover, rainfall levels were not gradually 'declining' prior to 2003; to the contrary, rainfall levels during the 1990s and early 2000s were generally above the thirty year average, with no major droughts after 1990 (Kevane and Gray, 2008, p. 4). This rainfall evidence is corroborated by evidence of a greening of Darfur (and the Sahel beyond) since the early 1990s which is visible through satellite imagery (Brown, 2010; Herrmann et al., 2005; Olsson et al., 2005). Darfur was not witness to 'desertification' prior to the war (UNEP, 2007) - this notion in any case being a problematic simplification (Swift, 1996; 
Thomas and Middleton, 1994) - and the war did not erupt 'during the drought' (Ban, 2007). Therefore, if precipitation changes and resulting vegetative transformations did have an impact on the Darfur war, the crucial factor must either have been the relative abundance post-1990 (a possibility for which for which we know of no evidence) or relative scarcities in the preceding decades, with a decade-plus time-lag to the war itself. Indeed, the obvious case of simultaneity between water scarcity and conflict onset in Sudan is not provided by the Darfur war, but the 1983-2005 civil war - but there is no suggestion in the existing literature that drought was a factor in this war's outbreak.

Just as water scarcity and conflict in Sudan have not been temporally correlated, so equally there is no clear spatial correlation between the two. During the Darfur war, the worst violence took place in areas of relatively good rainfall, along the southern and western fringes of the Jebel Marra highlands, and between there and the border with Chad - areas with 'amongst the richest agricultural lands in Sudan' (Mamdani, 2009, p. 10; see: US Department of State, 2004 for location of destroyed villages). Indeed, considering Sudan as a whole, the most perennial violence in the fifty plus years since independence has been in the states of southern Sudan - areas with the highest rainfall levels. It is also worth noting that, while there are of course huge internal differences in precipitation and water availability, Sudan as a whole is not water-scarce: total precipitation volume per capita in Sudan is over five times that in the UK, while total renewable water resources per capita are estimated at over $60 \%$ of the UK level (calculated from FAO, 2012a, 2012b). Risk analysts have ranked Sudan as 93rd or 'low risk' for water scarcity (Maplecroft, 2011).

A second problem with claims that internal water scarcities have caused conflict in the Sudans is that they rest upon stereotypical and outdated assumptions about Sudanese livelihoods and society. Consider Darfur, once again. In water scarcity readings of the Darfur war, it is thought that drought caused (or significantly contributed to) conflict by challenging traditional subsistence livelihoods, leading to migration from areas of environmental stress, and to heightened conflict amongst nomadic pastoralists, and between them and sedentary farmers (Ban, 2007; Faris, 2007). At least two assumptions are operative here: that Darfur's 'traditional' economy and society are utterly dominated and determined by the availability of water; and equally, that this traditionalism - Darfur's low level of development - was a crucial intervening variable between (claimed) water scarcities and the descent into war. Both of these premises are mistaken, however.

Far from being merely 'traditional', contemporary livelihoods across the Sudans are hybrid, dynamic, globally integrated and arguably therefore also distinctly 'modern'. The subsistence tribal peasant no longer exists in Darfur, and has not done for decades (de Waal, 1989, p. 55). Moreover, contrary to the oft-invoked distinction between 'nomads' and 'settled farmers', today nearly all farmers raise livestock, whilst nearly all pastoralists cultivate crops (Young and Osman, 2005, p. 10). Both livestock and crop production are heavily commercialised and export-oriented. While crops used to be Sudan's major export commodity, the livestock sector has recently experienced dramatic growth figures, making Sudan the leading livestock exporter in the region (Young and Osman, 2005, p. 52). This, in turn, was a direct result of the stateled liberalisation of the sector that began with the replacement of the parastatal Livestock and Meat Marketing Corporation with commercial livestock banks in 1992 (UNEP, 2012, p. 19). Farming practices continuously change and adapt, in response to assorted economic and environmental variables. Moreover, rural livelihoods in Darfur and across the Sudans are not solely dependent on local production and therefore water, but equally on remittances (especially from Libya, Saudi Arabia and other oil producer states: Young and Osman, 2005, pp. 83-108; Young et al., 2007) international aid (Sudan ranks amongst the largest recipients of overseas aid, most of it in the form of humanitarian aid, especially to Darfur, see: Poole, 2011), and public sector employment, especially in the security sector (one state salary in South Sudan being reported to maintain 30 people: Environment Water Security Workshop 2012).

Of course, the Sudans rank near the foot of most international development indicators, and Darfur is a relatively peripheral area within northern Sudan: to this extent, conflict in Darfur is broadly correlated with under-development. But not only with this, since the Darfur war also coincided with the early years of Sudan's oil boom. Oil exports from 1999 onwards spurred average annual GDP growth of $6.75 \%$ from 2000 to 2003 , compared with only $2.7 \%$ in the preceding 20 years (IMF, 2009). On the back of this oil-led growth, during the early 2000s there were significant increases in government revenues and expenditure, in the size of the agricultural sector, and in both international arms procurement and domestic military production (Patey, 2010; ICG, 2002). Whether there was any causal relationship between these developments and the war in Darfur, we cannot say. But this at least suggests that the Darfur war was as much correlated with processes of development, as its dearth.

Land disputes, migration and challenges to pastoralist livelihoods have all been widely recognised as significant contributors to political violence in Darfur and beyond (e.g. Assal, 2009; Unruh, 2012). However, none of these have been solely or even mainly rooted in either water scarcity or low development, but rather in a combination of colonial and post-colonial development practices. The British colonial era left a legacy of highly uneven land relations, in which contestation over property relations between tribes was aggravated, with some remaining dependent on access to others' land and water: this applies, for instance, to the Northern Reizegat, who played such a pivotal role in the Darfur war, constituting the bulk of the Janjawid militia (Mamdani, 2009). More recently, appropriative and conflict-ridden processes of development have involved, inter alia, the conversion of open rangelands into agricultural land, including irrigated land along seasonal rivers; the enclosure of both farmland and pastures, and the denial of open access to and free movement through these lands; and increased stock sizes - all of which have exacerbated both pressures on the environment and the aforementioned colonial legacies (Ayers, 2010; Barnett and Abdelkarim, 1987). Khartoum-led administrative reforms have also led to a decline of traditional conflict mechanisms, especially regarding land tenure (Suliman, 2010, p. 142). Next to these developments, drought has been a secondary and passing - though during particular periods crucial - factor. Poor rains during the 1970s and 1980s challenged existing livelihood strategies right across the Sahel, leading entire communities to migrate southwards, and contributing, perhaps decisively, to socio-economic changes in Darfur. However, even allowing for this, drought has not just been a determinant, compelling communities to migrate and change livelihoods: drought has also created opportunities. During the 1980s, some groups in Darfur migrated southwards not so much to escape drought and scarcity, but to access abundant pastures effectively 'opened up' by the southwards retreat of the tsetse fly (de Waal, 2007b). Equally, some groups, most notably the relatively wealthy Zaghawa, have migrated primarily during years of more plentiful rainfall (de Waal, 2007b). Neither land disputes, migration nor what Mamdani calls 'the crisis of nomadism across the entire Sahelian belt' (Mamdani, 2009, p. 211) are rooted essentially in water scarcity, or tradition and under-development, but rather in the violent contradictions of modernisation and development.

In addition to this, thirdly, water scarcity-conflict discourse on Sudan is premised on misunderstandings of the role of the state and elites in Sudanese politics, including the state's and Riverine 
elites' central role as agents of political violence. This political issue is often simply elided within scarcity-conflict discourse on Sudan, as if conflict were an automatic and reflexive product of scarcity, irrespective of political agency. Thus the aforementioned UNEP report concludes that 'there is a very strong link between land degradation, desertification and conflict in Darfur' despite admitting elsewhere that it had chosen 'not to investigate in detail the social and political aspects of conflicts in Sudan, focusing instead on their environmental dimensions' (UNEP, 2007, pp. 8, 73). Where politics is discussed within this discourse, it is primarily in terms of the absence of political agency and authority - that is, weak or failing statehood - not its decisive presence. For instance, in its most recent discussion of global strategic trends, the UK Ministry of Defence not only characterises conflict in Darfur as 'an example of how climate change may affect weak states,' but also restricts its discussion of the role of the Sudanese state to the observation that it 'lacked the necessary infrastructure and resources to respond to the crisis' (DCDC, 2010, p. 106).

Yet contrary to such claims, the Darfur war was essentially a brutal counter-insurgency operation, launched and financed by the government in Khartoum, and conducted by a combination of Sudanese army, intelligence and air force units, and paramilitary Janjawid brigades (who far from being independent of the state, often wore army uniforms, often operated in the company of regular army units, and would regularly undertake their attacks immediately after Sudanese Air force bombing raids: Prunier, 2005). The initial insurgency was not merely local either: politically, it was the product of Bashir's 'Palace Revolt' and 'breakdown of elite accommodation' within the NCP's clientelistic networks (Roessler, 2011a, p. 45) which in effect substituted a 'civil war risk for coup risk' (Roessler, 2011b, p. 302; also Gallab, 2008); whilst militarily, Darfur's rebel movements received significant political and military support from the principal national opposition, the Sudan People's Liberation Army/Movement. The Darfur conflict was also significantly influenced by Cold War era regional legacies, notably political crisis in the Chad and Gadaffi's panAfricanism - making the Darfur war not only political but geopolitical (e.g. Mamdani, 2009, pp. 213-220). The Darfur war, in sum, was a national and regional rather than merely local conflict, the most significant roots of which lay $1000 \mathrm{~km}$ away from the burning villages of West Darfur, on the banks of the Nile. And it was a conflict in which the Sudanese state was the central agent of violence. The Darfur war was not caused by scarcity, was as much associated with development as with under-development, and was as much about state power as state failure.

\section{Relative abundance, development and conflict}

By contrast with this limited evidence of scarcity-induced violent conflict, there is clear historical evidence in Sudan of links between relative water abundance and development, and ensuing violence. Indeed, some of the most violent episodes in Sudan's troubled history have involved attempts to capture water resources and water-rich lands, for agricultural (and more broadly socio-economic) development.

The most well known instance of this relates to the attempted construction of the Jonglei Canal in southern Sudan. The ambition behind this project was, and for some remains, to avoid evapotranspiration losses from the Nile by circumventing the Sudd swamps, and through so doing increasing Nile flow by up to $7 \mathrm{bm}^{3} /$ year - this volume to be shared equally between Sudan and Egypt (Ahmad, 2008, p. 578). Construction of the Canal started in 1978, and it soon became clear that promises made by the Sudanese and Egyptian authorities for community water supply projects alongside it were not being kept (Johnson, 2003, p. 48), while the Canal's construction was disrupting livelihoods and wildlife and cattle migration routes, causing significant resentment amongst the southern Sudanese, especially the cattle-herding Dinka, who saw the project as typifying Khartoum's policies of exploitation and neglect (Collins, 1988, p. 152; Lako, 1988). Indicative of this, the excavation machine used for digging the Canal was targeted by the Sudan People's Liberation Army at the onset of Sudan's second civil war. While this choice of target should not be interpreted as evidence that Sudan's second civil war was essentially hydro-political in its causes - oil installations were also targeted - it nonetheless encapsulates the intimate links that do exist between water development and conflict in Sudan.

Dam construction projects and irrigation schemes have also repeatedly led to displacement, dispossession and, in turn, political and sometimes violent conflict. The establishment of the Ghezira and Mangali schemes in the early nineteenth century gradually transformed a population of half a million into tenant farmers and wage labourers, this process involving the forced, and often violent, appropriation of common land, labour and water (Barnett, 1977; Beer, 1955, p. 44). 80,000 were displaced during the 1960s construction of the Roseries I Dam (Taha, 2010, p. 198), and a further 100,000 by the Aswan High Dam/Wadi Haifa project, leading to protests which continue to this day (Taha, 2010, p. 195). More recently, the construction of the Merowe Dam has involved the displacement of 50-70,000 (Sudan Tribune, 2008), and the recently completed heightening of the Roseries Dam in Blue Nile State is said to have displaced 22,000 families (Raziq, 2012). Ensuing protests have been violently suppressed in both cases (Abbas, 2012; Sudan Tribune, 2011).

Such examples pale into insignificance, however, relative to the widespread and near continuous violence which has raged across Sudan's semi-periphery since the 1980 s, associated with access to and the development of rain-fed agricultural land. Sudan's first civil war (1955-1972) was confined to the South, and was essentially rooted in political disagreements and objectives relating to the constitutional structure of the newly independent state. By contrast, Sudan's second civil war - or what subsequently became a network of multiple internal wars - has involved fighting in Southern Kordofan, Blue Nile, Kassala and Red Sea states, all parts of the 'Muslim North'. The post-2003 war in Darfur also fits into this category. These multiple conflicts have mainly been in 'intermediate' regions - that is, in areas which are politically and economically semi-peripheral, lying neither in Sudan's Northern Nile state heartlands nor in the Southern periphery; and which are mostly also ecologically transitional, lying between the Sahara to the north and the equatorial zone to the south. The fundamental reason for this geographical shift is that resource appropriation has been a central cause and objective of the multiple wars witnessed in Sudan since the 1980s, but was not a central cause of the first civil war; and that it has been in Sudan's semi-periphery 'where asset transfer' - especially the appropriation of rain-fed land - 'has been most marked' (Johnson, 2003, p. 145).

Nowhere have these dynamics been more in evidence than in the Nuba Mountains of South Kordofan. The Nuba Mountains region and their majority Nuba population have long been targeted by the Sudanese state and reverine elite, both on ethnic-cultural grounds, and with an eye to the appropriation of rain-fed agricultural land for cotton production. This reached its height in the early 1990s when an estimated 20-30,000 Nuba were deported to resettlement camps known as 'peace villages', and forced to work in large-scale mechanised farming schemes (Salih, 1995, p. 76), their appropriated land then being auctioned to Arab businesses and settlers by the Sudanese Ministry of Planning (Johnson, 2003, p. 133). Here, as elsewhere in Sudan's semiperiphery, it has been relative abundance rather than scarcity which has been most consistently associated with conflict. As Johnson notes, "[i]t has been one of the major ironies of the war that 
the actual and potential wealth of southern societies, and the southern Sudan as a whole - be it in land, livestock, water, oil or minerals - has been the source of their vulnerability' (Johnson, 2003, p. 75; Keen, 2008).

It is not just this wealth and availability of resources that has driven this pattern of violence, however, but also an underlying political economic regime. In Sudan, this regime was established by General Nimery's 1970s 'infitah' economic liberalisation policies (Elnur, 2008, p. 40), which opened the door to Arab Gulf petro-dollars, in turn providing the capital for an expansion of mechanised farming under the supervision of the IMF and World Bank. From then onwards, cultivating export-oriented crops beyond the traditional Nile state cotton plantations, and becoming 'Africa's Breadbasket', became central to Sudan's development policy. Politically this was sustained by simultaneous processes of centralization, especially through the abolition of colonial 'Native Administrations', and the commoditization of communal land through the 1971 Unregistered Land Act. Built on the three pillars of Arab finance, Western know-how and Sudanese resources, this globalised process (Ayers, 2010) of 'accumulation by dispossession' of traditional forms of subsistence (Abdelkarim, 1992; cf. Harvey, 2009) led to a constant but unsustainable agricultural expansion that depleted soils and other resources (Suliman, 1997), and fuelled the local conflicts discussed above. As Verhoeven (2011b) and others have point out, this developmental regime continues to be reformulated by successive Sudanese governments to this day. It deserves emphasising, though, that the reproduction of this developmental regime is not only a product of elite strategy, but is tightly wedded into, and determined by, processes of global accumulation (Ayers, 2010, 2013).

The linkages between abundance, development and conflict in Sudan are not specific to its post-colonial history, however: they have a very long historical lineage. Relative water abundance was a key motivation behind the Anglo-Egyptian colonisation of Sudan in the 1890s. Egyptian cotton production, so crucial to British textile production and the imperial economy, was dependent upon and limited by summer Nile flows - which could not be further controlled or increased from within the borders of Egypt. Water development upstream of Egypt, and just as importantly the monitoring of irregular Nile flows, thus became crucial to imperial strategy. Recognising this, Cromer characterised 'the effective control of the waters of the Nile from the Equatorial Lakes to the sea' as a central motive behind the occupation of Sudan (Cromer, 1908). Indeed, while interpretations vary, some have characterised the British colonisation of Sudan as 'essentially hydrological' in its aims (Tvedt, 2011, p. 174, also: 2004). Whether this is the case or not, the linkages here between water abundance, development and political violence are beyond doubt. Kitchener's military campaigns up the Nile - culminating in the 'battle' of Omdurman, at which 11,000 Sudanese were slaughtered, against only 49 AngloEgyptian losses (Holt and Daly, 2000, p. 96; Lindqvist, 1996, p. 46) and the subsequent half-century of Anglo-Egyptian colonial rule in Sudan were either partially or primarily rooted in hydro-political ambitions. From the colonial era to the present, the links between water abundance, water development and violent conflict have been a recurrent theme of Sudanese politics.

\section{Conclusions}

We can now revisit our six hypotheses in light of the foregoing. So, first: it is clear that, at least geographically, conflict in the Sudans has been more intimately associated with local environmental abundance than with scarcity. The location of water and rain-fed agriculture-related conflicts in the Sudd, in the Nuba Mountains, across Sudan's semi-periphery as a whole, and indeed during the Anglo-Egyptian colonisation of Sudan all testify that the geography of water abundance has had longstanding and enduring impacts on the geography of conflict in the Sudans. Temporally, no equivalent scale linkages exist - for the simple reason that no new water resources have been created or discovered. At communal levels, there is some evidence that the drilling of new boreholes by aid agencies and NGOs regularly leads to conflict over newly abundant waters (Workshop, 2012). By contrast, at a more macrolevel, the one change in water availability that can plausibly be linked to conflict relates not to abundance, but to scarcity. The Sahel drought of the 1970s and ' 80 s left a bitter social and economic legacy that arguably culminated, twenty years later, in the 2003-2005 war. But by comparison with the direct evidence of abundance-related violence, the linkages here are indirect, timelagged and in any case contestable. In the Sudans, conflict has been much more directly linked to water abundance than to water scarcity.

Secondly, however, this does not mean that these conflicts were caused by 'abundance' - since local abundance only assumes importance, and only exists, relative to 'scarcities' elsewhere. The Jonglei Canal was an attempt to capture the abundant resources of the Sudd on behalf of agricultural interests in the Upper Nile Valley, and to this extent was as much about (visions of) scarcity in Cairo and Khartoum as it was about abundance to the south. For Kitchener's campaign up the Nile, the same applies (though with the qualification that the aims of this campaign were probably only in part hydrological). In this regard water is no different from diamonds or oil: all resource-related conflicts revolve around the relations between scarcity and abundance - 'scarcity-abundance' and are never about one or the other of these 'variables' treated in isolation. The existing quantitative literature on environmental and resource conflicts is profoundly mistaken in treating them as such.

Notwithstanding the above, thirdly, the importance of these water-related conflicts should not be over-stated: water, and the political and economic relations associated with it, have not been the primary drivers of conflict in the Sudans. Oil is much more important to the two countries' political economies, accounting, in the South, for 98\% of government revenues (Patey, 2010). Oil wealth sharing provisions were central to the Comprehensive Peace Agreement. And in turn, since the South's 2011 secession, oil has been the major source of North-South political and military confrontation, leading for much of 2012 to a full-scale shut-down of Southern oil production. Water, by contrast, is generally not a route to substantial wealth and power. It barely figured within the Comprehensive Peace Agreement (Rolandsen, 2011, p. 558). There have been no significant post-secession disputes over watersharing. And there is little sign of any such disputes coming to pass. The central reason for this is that, within the context of contemporary global capitalism, water is not a source of significant rents, or in turn a significant part of the armoury of state and elite power.

Fourthly, political economic dynamics, rather than changes in resource availability, have been the main proximate determinants of environment-related conflict in the Sudans. The construction of the Jonglei Canal was determined not by any sudden or secular scarcity, but by political changes in Khartoum. Likewise, land appropriation in the Nuba Mountains was not a response to emerging land shortages, but was rather part of a state-led project of expanding mechanised agriculture, and of 'accumulation by dispossession' (Harvey, 2009). In both cases, environment-related conflict occurred in the absence of, or irrespective of, environmental change. The latter is neither a sufficient, nor even a necessary, condition for environment-related violence.

Rather than environmental change, it is political economic factors which have been the main determinants of water-related violence in the Sudans. These factors have been at once local, 
regional and global. Imperial and cotton interests first led Britain down the Nile, resulting in the Sudan's forcible integration into the then British-dominated world economy, and in turn to the hydraulic development and violent transformation of its central riverine states. Egyptian-Sudanese collaboration lay behind the Jonglei Canal. And the more recent water and land-related conflicts across Sudan's semi-periphery have all been determined by political economic factors: by the global turn to neo-liberalism from the 1970s onwards; by Sudan's extreme indebtedness; by the influence of the World Bank and IMF; by the oil boom of the 1970s and '80s; and, not least, by the interests of Khartoum's elites and its liberalising but military regime. If representative, this suggests that it is local but globally-embedded political economic processes - simultaneously processes of development and state-building which are the key to understanding environment-conflict relations in peripheral states like the Sudans.

To what extent might these findings hold true, and to what extent might this model still apply, under circumstances of global climate change? Global Circulation Model projections offer little clear guidance: while on average they suggest small precipitation increases across most of Sudan and South Sudan, individual Global Circulation Model projections diverge strongly (for example, individual projections for Nyala in Darfur for the period 20402069 , suggest anywhere from a $21 \%$ increase in precipitation to a $25 \%$ decrease: Bruggeman et al., 2010, p. 41). Indeed, the only changes that can be predicted with any degree of confidence are that temperatures will rise, perhaps by up to $2.5^{\circ} \mathrm{C}$ by $2040-2069$ (Bruggeman et al., 2010, p. 20), in turn increasing evapo-transpiration losses; and that there will be an increased incidence of precipitation extremes. Other changes are also likely, including further increases in water demand stemming from population growth and agricultural development, both internally within Sudan and elsewhere in the Nile basin (especially in Egypt and Ethiopia). But the potential impact of these should not be overstated. Yes, Ethiopia has ambitious water development plans, but these do not involve large net increases in water abstraction: the main purpose of its dam-building is electricity generation, not irrigation (el Hatow, 2012); and increased water storage in the Ethiopian highlands could conceivably lead, within the context of an integrated basin-wide regime, to significant savings from the $10 \mathrm{bm}^{3} /$ year evaporation currently lost from Lake Nasser (Cheterian, 2012; Verhoeven, 2011a, p. 12). And yes, the Nile basin's total population may grow by as much as 53\% by 2030 (UN, 2012), but continuing urbanisation will likely moderate the impacts of this on rural livelihoods. Nile riparians already rely on virtual water imports more than they do on the Nile itself (Zeitoun et al., 2010), and could make even greater use of such imports. The Nile is not inexorably becoming a site of scarcity, let alone scarcity-induced conflict.

What will determine future patterns of environment-related conflict in the Sudans is not so much the level of the Nile, nor climate change, but the two countries' political economies, the strategies adopted by local elites, and the global dynamics in which these are embedded. The loss of up to 75\% of Sudan's hydro-carbon income following southern secession will require nothing short of a re-invention of the Sudanese economy (Verjee, 2012). Sudan currently faces high unemployment rates, a high public deficit, high inflation rates and high international debt, currently combined with an internationally-monitored austerity programme (ADBG, 2013). Military expenditure also remains high, reflecting the continuing conflicts in Darfur, Abyei, Blue Nile and South Kordofan, and the military basis of the Khartoum regime. As in the past, this situation could well inspire aggressive state strategies, including the violent appropriation of land and water.

In South Sudan, equally, oil and donor dependency, the size of the security sector (accounting for $40 \%$ of government spending) and large-scale internal violence, including periodic military engagements with the North, are such that it is hard to imagine that South Sudan's future will be anything but conflict-laden. Water may quite conceivably be part of this. While historical experience has made water development schemes politically sensitive, even the Jonglei Canal is not rejected on principle by the South Sudanese leadership (Ahmad, 2008; Sudan Tribune, 2009; Interview, 2011a); and Egypt continues to express its interest in the realisation of the project (Sullivan and Nasrallah, 2010, p. 11; Taha, 2010). Moreover, increased agricultural production has already been singled out as one of the cornerstones of the future South Sudanese economy (GRSS, 2011), which will increase the conflict potential of water-rich land (UNHCR, 2012), not least if these become sites of 'land grabs' by foreign investors (Deng, 2011). Any of these developments could have violent consequences.

More generally, there is no reason to suppose that climate change will lead to a reversal of the dynamics described above either in the Sudans or elsewhere. The capture of relatively abundant resources, linked to processes of internal colonisation and economic development, will likely continue to be a cause of conflict in the global periphery. Indeed, one implication of the above is that state strengthening and economic development routinely advocated by international development actors as the main ways of mitigating resource scarcities, and building adaptive capacities - may significantly exacerbate patterns of environmentrelated conflict (Verhoeven, 2011b). If this is indeed correct, then the main conflict risk posed by climate change in contexts like the Sudans might not be increased scarcity, but rather renewed patterns of exploitation and appropriation informed - or legitimised - by new discourses of climate crisis.

\section{References}

Abbas, R., 2012. No Clear Studies on Impacts of Merowe Dam. Inter Press Service, http://www.ipsnews.net/2012/01/sudan-no-clear-studies-on-impacts-ofmerowe-dam/ (accessed 19.4.13).

ADBG, 2013. African Economic Outlook - Sudan. African Development Bank Group, http://www.africaneconomicoutlook.org/en/countries/east-africa/sudan/ (accessed 16.4.13).

Abdelkarim, A., 1992. Primitive Capital Accumulation in the Sudan. Routledge, London.

Abdel-Latif, M.M., Yacoub, M., 2011. Effect of change of discharges at Dongola station due to sedimentation on the water losses from Nasser Lake. Nile Basin Water Science \& Engineering Journal 4, 86-98.

Ahmad, A.M., 2008. Post-Jonglei planning in southern Sudan: combining environment with development. Environment and Urbanization 20, 575-586.

Ali, A.A.E., 2011. Egypt seeks Food and Water Security in Sudan. AFP, http://www.google.com/hostednews/afp/article/ALeqM5jtfMUKrVYKRNiOLcGgrQbOmI9LGg?docId=CNG.82fce0d1e069b2865b114176f57c0264.4a1 (accessed 22.3.13).

Assal, M., 2006. Sudan: identity and conflict over natural resources. Development 49, 101-105

Assal, M., 2009. The relationship between nomadic and sedentary people in Sudan in the context of state policies and internationalization. Nomadic Peoples 13, $154-170$.

Ayers, A.J., 2010. Sudan's uncivil war: the global-historical constitution of political violence. Review of African Political Economy 37, 153-171.

Ayers, A.J., 2013. Beyond myths, lies and stereotypes: the political economy of a 'new scramble for Africa'. New Political Economy 18, 227-257.

Baechler, G., 1999. Violence through Environmental Discrimination: Causes, Rwanda Arena and Conflict Model. Kluwer Academic Publishers, Dordrecht.

Ban, K.-M., 2007. A climate culprit in DarfurIn: The Washington Post. , 16.06.07.

Ban, K.-M., 2011. Security Council, in Statement Says "Contextual Information" on Possible Security - Implications of Climate Change Important When Climate Impacts Drive Conflict, http://www.un.org/News/Press/docs/2011/ sc10332.doc.htm.

Barnes, J., 2012. Pumping possibility: agricultural expansion through desert reclamation in Egypt. Social Studies of Science 42, 517-538.

Barnett, J., Adger, W.N., 2007. Climate change, human security and violent conflict. Political Geography 26, 639-655

Barnett, T., 1977. The Gezira Scheme: An Illusion of Development. Cass, London.

Barnett, T., Abdelkarim, A. (Eds.), 1987. Sudan: State, Capital and Transformation. Routledge, London.

Beer, C.W., 1955. Social development in the Gezira Scheme. African Affairs 54, $42-$ 51.

Benjaminsen, T., 2008. Does supply-induced scarcity drive violent conflicts in the African Sahel? The case of the Tuareg rebellion in northern Mali. Journal of Peace Research 45 (6) 819-836. 
Bromwich, B., 2009. Analysing resource constraints as one dimension of the conflict in Darfur. In: Environment and Conflict in Africa: Reflections on Darfur. University of Peace, Addis Ababa, pp. 110-122.

Brown, I.A., 2010. Assessing eco-scarcity as a cause of the outbreak of conflict in Darfur: a remote sensing approach. International Journal of Remote Sensing 31, $2513-2520$.

Bruggeman, A., Hadjinicolaou, P., Lange, M., 2010. Climate outlooks for CLICO case study sites (No. SSH-CT-2010-244443) The Cyprus Institute, CLICO, EC FP7 Programme, Nicosia.

Call, C.T., 2008. The fallacy of the 'failed state'. Third World Quarterly 29, 1491 1507

Cheterian, V., 2012. Egypt: the Nile and the revolution. openDemocracy 08.12.11.

Christian Aid, 2007. Human Tide: The Real Migration Crisis, http://www.christianaid.org.uk/Images/human-tide.pdf.

CNA Corporation, 2007. National Security and the Threat of Climate Change, http:// www.npr.org/documents/2007/apr/security_climate.pdf.

Collier, P., Hoeffler, A., 2005. Resource rents, governance, and conflict. Journal of Conflict Resolution 49, 625-633.

Collins, R.O., 1988. The Jonglei Canal: illusion or reality? Water International 13 , $144-153$.

Cramer, C.D., 2006. Civil War is Not a Stupid Thing: Accounting for Violence in Developing Countries. Hurst, London.

Cromer, E.B., 1908. Modern Egypt. General Books, New York.

Davis, M., 2002. Late Victorian Holocausts: El Nino Famines and the Making of the Third World. Verso, London.

DCDC, 2010. Global Strategic Trends - Out to 2040. Ministry of Defence, London.

de Waal, A., 2007a. War in Darfur and the Search for Peace. Harvard University Press, Cambridge, MA.

de Waal, A., 2007b. Is climate change the culprit for Darfur? Making Sense of Sudan Blog. , http://africanarguments.org/2007/06/25/is-climate-change-the-culpritfor-darfur/.

de Waal, A., 1989. Famine that Kills: Darfur, Sudan, 1984-1985. Oxford University Press, Oxford.

Deng, D.K., 2011. The New Frontier: A Baseline Survey of Large-Scale Land-Based Investments in Southern Sudan. Norwegian People's Aid, Oslo.

el Hatow, L., 2012. The Construction of Ethiopian Dams: An Act of War or Opportunity? Midan Masr Nile Supplement. , http://www.midanmasr.com/en/ pdfviewer/nilesupplementEnglish.htm\#page/1/mode/2up.

Ellis, S., 2005. How to rebuild Africa. Foreign Affairs 135-148.

Elnur, I., 2008. Contested Suda: The Political Economy of War and Reconstruction. Routledge, New York.

Falkenmark, M., 1989. Middle East hydro-politics: water scarcity and conflicts in the Middle East'. Ambio 18, 350-352.

FAO, 2009. Country Profile Egypt, http://www.fao.org/nr/water/aquastat/countries/ cyprus/index.stm.

FAO, 2012a. Country Fact Sheet United Kingdom. FAO Aquastat, http://www.fao.org/ $\mathrm{nr} /$ water/aquastat/data/factsheets/aquastat_fact_sheet_gbr_en.pdf.

FAO, 2012b. Country Fact Sheet Sudan and South Sudan. FAO Aquastat, http:// www.fao.org/nr/water/aquastat/data/factsheets/aquastat_fact_sheet_sdn_en.pdf.

Faris, S., 2007. The real roots of Darfur. The Atlantic, http://www.theatlantic.com/ magazine/archive/2007/04/the-real-roots-of-darfur/305701/.

Fearon, J.D., 2005. Primary commodity exports and civil war. Journal of Conflict Resolution 49, 483-507.

Gallab, A.A., 2008. The First Islamic Republic: Development and Disintegration of Islamism in the Sudan. Aldershot, Ashgate.

Gleditsch, N.P., Furlong, K., Hegre, H., Lacina, B., Owen, T., 2006. Conflicts over shared rivers: resource scarcity or fuzzy boundaries? Political Geography 25, 361-382.

Gleditsch, N.P., 2012. Whither the weather? Climate change and conflict. Journal of Peace Research 49, 3-9.

Gleick, P.H., 1993. Water and conflict: fresh water resources and international security. International Security 18, 79-112.

Gore, A., 2006. An inconvenient truth.

GoS, SPLM/A, 2005. The Comprehensive Peace Agreement between the Government of the Republic of the Sudan and The People's Liberation Movement/Sudan People's Liberation Army.

Granit, J., Cascao, A., Jacobs, I., Christina Leb, Lindström, A., Tignino, M., 2011. The Nile Basin and the Southern Sudan Referendum. Water Governance Facility, Stockholm.

GRSS, 2011. South Sudan Development Plan 2011-2013. Government of the Republic of South Sudan, Juba.

Halliday, F., 1994. Rethinking International Relations. University of British Columbia Press, Vancouver.

Halperin, S., 2004. War and Social Change in Modern Europe: The Great Transformation Revisited. Cambridge University Press, Cambridge.

Hamad, O.E.-T., 1998. Appendix 9: Country Case Study-National Water Policy in the Sudan, http://www.fao.org/docrep/006/ad456e/ad456e0f.htm (accessed 4.19.13).

Harvey, D., 1996. Justice, Nature and the Geography of Difference. Blackwell Oxford.

Harvey, D., 2009. The 'new' imperialism: accumulation by dispossession. Socialist Register 40.

Herrmann, S.M., Anyamba, A., Tucker, C.J., 2005. Recent trends in vegetation dynamics in the African Sahel and their relationship to climate. Global Environmental Change 15, 394-404.

Hokanson, C., 2007. UN leader addresses global warming, genocide. The Battalion, 03.03.08
Holt, P.M., Daly, M.W., 2000. A History of the Sudan: From the Coming of Islam to the Present Day. Longman, Harlow.

Homer-Dixon, T., 2007. Terror in the weather forecast. New York Times.

Homer-Dixon, T.F., 1999. Environment, Scarcity, and Violence. Princeton University Press, Princeton.

Huhne, C., 2011. The geopolitics of climate change. 07.07.11In: Speech to Future Maritime Operations Conference. Royal United Services Institute, London. , http:// www.decc.gov.uk/en/content/cms/news/chsp_geopol/chsp_geopol.aspx.

ICA, 2012. Global Water Security. Intelligence Community Assessment Office of the Director of National Intelligence, Washington DC. , http://dni.gov/files/documents/Newsroom/Press\%20Releases/ICA_Global\%20Water\%20Security.pdf (accessed 6.2.2014)

ICG, 2002. God, Oil and Country - Changing the Logic of War in Sudan. Africa Report No39 International Crisis Group Press, Brussels.

ICG, 2010. Sudan: Regional Perspectives on the Prospect of Southern Independence. International Crisis Group Press, Brussels.

ICG, 2011. Stopping the Spread of Sudan's New Civil War. International Crisis Group Press, Brussels.

IMF, 2009.In: International Monetary Fund World Economic Outlook Database. April 2009. IMF, Washington.

IPCC, 2001. Third Assessment Report: Climate Change 2001: Working Group 2: Impacts, Adaptation and Vulnerability. Cambridge University Press, Cambridge.

IPCC, 2007. Fourth Assessment Report: Climate Change 2001: Working Group 2: Impacts, Adaptation and Vulnerability. Cambridge University Press, Cambridge.

Johnson, D.H., 2003. The Root Causes of Sudan's Civil Wars. James Currey, Oxford.

Johnson, H.F., 2011. Waging Peace in Sudan: The Inside Story of the Negotiations that Ended Africa's Longest Civil War. Sussex Academic Press, Portland, OR.

Johnson, V., Fitzpatrick, I., Floyd, D., Simms, A., 2011. What is the evidence that scarcity and shocks in freshwater resources cause conflict instead of promoting collaboration? CEE Review 10-010.

Kahl, C.H., 2006. States, Scarcity and Civil Strife in the Developing World. Princeton University Press, Princeton, NJ.

Keen, D., 2008. The Benefits of Famine: A Political Economy of Famine and Relief in Southwestern Sudan, 1983-1989. James Currey, Oxford.

Keen, D., 2001. Sudan: conflict and rationality. In: Stewart, F., Valpy, F. (Eds.), War and Underdevelopment: II, vol. 2. Oxford University Press, Oxford.

Kevane, M., Gray, L., 2008. Darfur: rainfall and conflict. Environmental Research Letters 3, 1-10.

Koubi, V., Spilker, G., Böhmelt, T., Bernauer, T., 2013. Do natural resources matter for interstate and intrastate armed conflict? Journal of Peace Research, Online First.

Lako, G.T., 1988. The Jonglei scheme: the contrast between government and Dinka views on development. In: Sudan, State, Capital and Transformation. Croom Helm, London, pp. 85-98.

Leach, M., Mearns, R., 1996. The Lie of the Land: Challenging Received Wisdoms on the African Environment. James Currey, Oxford.

Lindqvist, S., 1996. Exterminate All The Brutes. New Press.

Logan, J., Preble, C., 2010. Washington's newest bogeyman. Strategic Studies Quarterly 17, 13-38.

Luoi, M.J., 2010. Water matters in the April 2010 Sudan electionsIn: Sudan Tribune. , 25.02.10.

Malone, B., 2010. Ethiopian PM warns Egypt off Nile War. Reuters.

MALR, 2012. Joint Egyptian Farms in Africa Arab Republic of Egypt - Ministry of Agriculture and Land Reclamation - Foreign Agricultural Relations, http://farmalr.gov.eg/en/farms.php.

Mamdani, M., 2009. Saviors and Survivors. Three Rivers Press,

Maplecroft, 2011. Maplecroft index identifies Bahrain, Qatar, Kuwait and Saudi Arabia as world's most water stressed countries, http://maplecroft.com/about/ news/water_stress_index.html (accessed 4.19.13).

Mayoum, M., 2010. Lakes' Agaar-Pakam and Warrap's Luanyjang sign peace 26.03.10In: Sudan Tribune., http://www.sudantribune.com/Lakes-AgaarPakam-and-Warrap-s,34541.

Mazo, J., 2010. Climate Conflict: How Global Warming Threatens Security and What to Do About It. Routledge, London.

Mehta, L., 2010. The Limits to Scarcity: Contesting the Politics of Allocation. Earthscan, London.

Mjøs, O.D., 2007. Speech given by The Chairman of the Norwegian Nobel Committee. Oslo 10.12 .07

Moore, B., 1967. Social Origins of Dictatorship and Democracy: Lord and Peasant in the Making of the Modern World. Penguin, London.

Moussa, J., 2012. Adjudicating the Nile Crisis. Midan Masr The Nile Special Supplement, http://www.midanmasr.com/en/pdfviewer/nilesupplementEnglish.htm\# page/1/mode/2up.

Murshed, S.M., 2002. Conflict, civil war and underdevelopment: an introduction. Journal of Peace Research 39 (4) 387-393.

MWRI, 2010. Water Challenges in Egypt. Ministry of Water Resources and Irrigation, Cairo. , http://www.mwri.gov.eg/En/pdf_files\%20english/Brochure\%20\%20Eng.pdf.

Nordås, R., Gleditsch, N.P., 2007. Climate change and conflict. Political Geography 26, 627-638.

Olsson, L., Eklundh, L., Ardö, J., 2005. A recent greening of the Sahel: trends, patterns and potential causes. Journal of Arid Environments 63, 556-566.

Omer, A.M., 2007. Water resources and freshwater ecosystems in Sudan. Renewable and Sustainable Energy Reviews 12, 2066-2091.

Patey, L., 2010. Crude days ahead? Oil and the resource curse in Sudan. African Affairs 109, 617-636.

Peluso, N., Watts, M., 2001. Violent Environments. Cornell University Press, Ithaca. 
Poole, L., 2011. Aid to Sudan, 1995-2009 - new GHA factsheet - Global Humanitarian Assistance. Global Humanitarian Assistance, http://www.globalhumanitarianassistance.org/aid-to-sudan-1995-2009-new-gha-factsheet-2737.html (accessed 4.19.13).

Prunier, G., 2005. Darfur: The Ambiguous Genocide. Hurst, London.

Raziq, Z., 2012. Al-Mahdi's Umma Party congratulates Sudanese on RoseirisIn: Sudan Vision Daily. , http://news.sudanvisiondaily.com/details.html?rsnpid=217758 (accessed 4.19.13).

Rolandsen, O., 2011. A quick fix? A retrospective analysis of the Sudan Comprehensive Peace Agreement. Review of African Political Economy 38 (130) 551-564.

Roessler, P., 2011a. The enemy within: personal rule, coups, and civil war in Africa. World Politics 63, 300-346.

Roessler, P., 2011b. Internal rivalry, threat substitution and civil war: Darfur as a theory-building case, http://dx.doi.org/10.2139/ssrn.1909228 (accessed 9.4.13).

Rupert, M., Smith, H., 2002. Historical Materialism and Globalisation. Routledge, London.

Sachs, J., 2005. Interview Transcript from Talk, the End of Poverty: Economic Possibilities for our Time. Carnegie Council.

Sachs, J., 2006. Ecology and Political Upheaval.

Salman, S.M.A., 2011. The new state of South Sudan and the hydro-politics of the Nile Basin. Water International 36, 154-166.

Salih, M., 1995. Resistance and response: Ethnocide and genocide in the Nuba Mountains. GeoJoumal 36, 71-78.

Selby, J., 2005a. Oil and water: the contrasting anatomies of resource conflicts. Government and Opposition 40, 200-224.

Selby, J., 2005b. The geopolitics of water in the Middle East: fantasies and realities. Third World Quarterly 26, 329-349.

Stavrianakis, A., Selby, J., 2012. Militarism and international relations in the 21st century. In: Stavrianakis, A., Selby, J. (Eds.), Militarism and International Relations: Political Economy, Security, Theory. Routledge, London, pp. 5-11.

Sudan Tribune, 2008. Merowe dam floods thousands in area closed to outsiders, http://www.sudantribune.com/spip.php?page=imprimable\&id_article=28812 (accessed 4.19.13).

Sudan Tribune, 2009. Jonglei canal project needs to be revised. South Sudan says, http://www.sudantribune.com/Jonglei-canal-project-needs-to-be,32062 (accessed 4.19.13).

Sudan Tribune, 2011. Sudanese police clamp down on water cuts protestors, http:// www.sudantribune.com/Sudanese-police-clamp-down-on,39945.

Suliman, M., 1997. Civil war in Sudan: the impact of ecological degradation. Contributions in Black Studies 15, 99-121.

Suliman, O., 2010. The Darfur Conflict: Geography or Institutions? Routledge, London.

Sullivan, P., Nasrallah, N., 2010. Improving Natural Resource Management in Sudan: A Strategy for Effective State Building and Conflict Resolution. United States Institute for Peace Special Report 242, pp. 1-20.

SUNA, 2009. Sudan Participation in the International Climate Summit, http:// www.sunanews.net/english-latest-news/7056-sudan-participation-international-climate-summit-translated-belgees-fagairi.html (accessed 3.22.13).

Swain, A., 2011. Challenges for water sharing in the Nile basin: changing geopolitics and changing climate. Hydrological Sciences Journal 56, 687-702.

Swift, J., 1996. Desertification: narratives, winners and losers. In: The Lie of the Land: Challenging Received Wisdom on the African Environment. James Currey, Oxford, pp. 73-90.

Taha, F., 2010. The history of the Nile waters in the Sudan. In: The River Nile in the Post-Colonial Age: Conflict and Cooperation Among the Nile Basin Countries. IB Tauris, London, pp. 179-216.

Theisen, O.M., 2008. Blood and soil? Resource scarcity and internal armed conflict revisited. Journal of Peace Research 45/6, 801-818.

Thomas, D.S.G., Middleton, N.J., 1994. Desertification: Exploding the Myth. Wiley.

Tilly, C., 1985. War Making and State Making as Organized Crime. In: Evans, P., Rueschemeyer, D., Skocpol, T. (Eds.), Bringing the State Back In. Cambridge University Press, Cambridge.

Tisdall, S., 2011. Conflict in Darfur is my responsibility, says BashirIn: The Guardian. , 21.04.11.

Tvedt, T., 2004. The River Nile in the Age of the British: Political Ecology and the Quest for Economic Power. IB Tauris, London.
Tvedt, T., 2011. Hydrology and empire: the Nile, water imperialism and the partition of Africa. The Journal of Imperial and Commonwealth History 39, 173-194.

UAR/Sudan, 1959. United Arab Republic and Sudan Agreement for the Full Utilization of the Nile Waters, http://ocid.nacse.org/qml/research/tfdd/toTFDDdocs/ 110ENG.pdf.

UK Cabinet Office, 2008. The National Security Strategy of the United Kingdom: Security in an Interdependent World. HMSO, London.

UN, 2012. World Population Prospects: The 2012 Revision. United Nations, Department of Economic and Social Affairs, Population Division, http://esa.un.org/ wpp/unpp/panel_population.htm (accessed 5.9.2013).

UNAMID, 2011. International effort launched to tackle water scarcity and conflict in Darfur, http://unamid.unmissions.org/Default.aspx?ctl=Details\&tabid=11027\& mid $=14214$ \&ItemID $=17549$.

UNEP, 2007. Sudan: Post-Conflict Environmental Assessment. Nairobi.

UNEP, 2008. Water Resource Management in Humanitarian Programming in Darfur: The Case for Drought Preparedness. United Nations Environment Programme, Geneva.

UNEP, 2012. UK Government Donor Visits UNEP Environment and Peacebuilding Projects in Sudan, http://www.unep.org/Documents.Multilingual/Default.asp? DocumentID=2676\&ArticleID=9060\&l=en.

UNHCR, 2012. South Sudan: Pressure on Land, Water as More Refugees Enter the Country. Press Release, http://www.unhcr.org/4fc8b5409.html.

Unruh, J.D. 2012. Land and legality in the Darfur conflict. African Security 5, 105-128.

UNSC, 2011. United Nations Security Council, Special report of the SecretaryGeneral on the Sudan, S/2011/314, http://www.un.org/ga/search/view_doc.asp?symbol=S/2011/314 (accessed 3.14.13).

US Department of State, The Office of Electronic Information, 2004. Documenting Atrocities in Darfur, http://2001-2009.state.gov/g/drl/rls/36028.htm (accessed 4.19.13).

Verhoeven, H., 2011a. Black Gold for Blue Gold? Sudan's Oil, Ethiopia’s Water and Regional Integration. Chatham House, London.

Verhoeven, H., 2011b. Climate change, conflict and development in Sudan: global neo-Malthusian narratives and local power struggles. Development and Change.

Verhoeven, H., 2013. Why a 'water war' over the Nile River won't happen. AlJazeera English, http://www.aljazeera.com/indepth/opinion/2013/06/ 2013612105849332912.html (accessed 9.12.13).

Verjee, A., 2012. New north, old north: the Republic of Sudan after the split. In: Sudan After Separation: New Approaches to a New Region. Boell Foundation, Berlin, pp. 35-45.

Waterbury, J., 1979. Hydro-politics of the Nile Valley. Syracuse University Press.

Wikileaks, 2010. The Global Intelligence Files - Re: Egypt source 29.7.2010, http:/ wikileaks.org/gifiles/docs/211372_re-egypt-source-.html (accessed 3.14.13).

Wolf, A.T., 1998. Conflict and cooperation along international waterways. Water Policy 1, 251-265.

Young, H., Osman, A.M.K., 2005. Darfur: Livelihoods under Siege. Tufts University: Feinstein International Famine Center, Medford, MA.

Young, H., Osman, A., Dale, R., 2007. Darfurian livelihoods and Libya: trade migration, and remittance flows in times of conflict and crisis. International Migration Review 41, 826-849.

Young, J., 2012. The Fate of Sudan: The Origins and Consequences of a Flawed Peace Process. Zed, London.

Zeitoun, M., Allan, J., Mohieldeen, Y., 2010. Virtual water "flows" of the Nile Basin, 1998-2004: a first approximation and implications for water security. Global Environmental Change 20, 229-242.

Zeitoun, M., Warner, J., 2006. Hydro-hegemony: a framework for analysis of transboundary water conflicts. Water Policy 8

\section{Further reading}

Workshop, 2012. Environment Water Security Workshop, 07.02.12 Juba Regency Hotel, Juba, Republic of South Sudan.

Interview, 2011a. Republic of South Sudan, Undersecretary Ministry of Water Resources and Irrigation February 2011.

Interview, 2011b. Arab Republic of Egypt, Consulate. Republic of South Sudan, Juba February 2011 